ISSN: 1110-5623 (Print) - 2090-0570 (Online)

\title{
COMPARATIVE STUDY BETWEEN DIETARY SUPPLEMENTATION OF GRAPE POMACE AND VITAMIN E AS ANTIOXIDANT ON SOME PRODUCTIVE, REPRODUCTIVE AND PHYSIOLOGICAL PERFORMANCE OF MALE AND FEMALE AGED INSHAS STRAIN CHICKENS.
}

\author{
A.K. Alm El-Dein ${ }^{1}$ - O.S. Rashed ${ }^{1}$ - M.M.M. Ouda ${ }^{2}$ Nasra, B. Awaden ${ }^{3}$ - \\ Inas I. Ismail ${ }^{1}$ - M.S. Mady $^{3}$
}

${ }^{1}$ Dep. of Poult. Breed. Res., Anim. Prod. Res. Inst., Agric. Res.Cent., Minis. of Agric., Dokki, Giza, Egypt. ${ }^{2}$ Poult. Res. Station (Inshas), Anim. Prod. Res. Inst., Agric. Res.

Cent., Minis. of Agric., Dokki, Giza, Egypt. ${ }^{3}$ Poult. Res. Station (Sakha), Anim. Prod. Res. Inst., Agric. Res. Cent., Minist. of Agric., Dokki, Giza, Egypt.

Corresponding author: Alaa Alm El-Dein, Email: alaa.alm010@gmail.com

\begin{tabular}{|c|c|}
\hline Received: 01/08/2017 & Accepted: 27/08/2017 \\
\hline $\begin{array}{l}\text { ABSTRACT: This work was carried } \\
\text { supplementation on some productive, } \\
\text { male and female Inshas strain chicken } \\
\text { nens and } 18 \text { cocks) } 48 \text {-wks-old were us } \\
\text { individually weighed and randomly di } \\
\text { and } 3 \text { cocks of each) with three replice } \\
\text { average initial live body weight of a } \\
\text { supplementation but the formula of } \\
\text { NRC, (1994), while the } 2^{\text {nd }}, 3^{\text {rd }} \text { and } 4^{\text {th }} \\
\text { with } 1,2,3 \text { and } 4 \% \text { grape pomace } \\
\text { supplemented with } 150 \mathrm{mg} \text { vit.E/ } \mathrm{kg} \\
\text { grape pomace were better than values } \\
\text { gercentage, egg mass, plasma superox } \\
\text { estosterone and the values had sign } \\
\text { oomace only compared to vit. E gro } \\
\text { exhibited the best values in all semen } \\
\text { tudied, with significant (P } \leq 0.05 \text { ) diff } \\
\text { for traits sperm motility, live sperm pe } \\
\text { otal live sperm per ejaculate, total } \\
\text { oercentage of both total and fertile e }\end{array}$ & $\begin{array}{l}\text { y the effect of dietary grape pomace and vit.E } \\
\text { e and physiological performance traits of aged } \\
\text { humber of } 198 \text { Inshas strain birds ( } 180 \text { laying } \\
\text { xperiment up to } 60 \text { wks of age. All birds were } \\
6 \text { equal experimental groups ( } 30 \text { laying hens } \\
\text { ing hens and } 1 \text { cock each) with nearly similar } \\
\text { The } 1^{\text {st }} \text { group was fed the basal diet without } \\
\text { d } 15 \mathrm{mg} \text { vit.E/kg diet (control) according to } \\
\text { oups were fed on the basal diet supplemented } \\
\text { and the } 6^{\text {th }} \text { group was fed the basal diet } \\
\text { sults showed that, values of levels } 3 \text { and } 4 \% \\
\text { feed conversion, egg number, egg production } \\
\text { se, plasma glutathione peroxidase and plasma } \\
\text { erences (P } \leq 0.05 \text { ) for the level of } 4 \% \text { grape } \\
\text { eral, the highest level of grape pomace (T5) } \\
\text { characteristics, fertility and hatchability traits } \\
\text { npared to vit. E (T6) and control (T1) groups } \\
\text { perm concentration, total sperm per ejaculate, } \\
\text { perm per ejaculate, fertility and hatchability } \\
\text { significant ( } \mathrm{P} \leq 0.05 \text { ) differences compared to } \\
\text { rmal sperm percentage. On the basis of these } \\
\text { ape pomace (natural source of antioxidant) as } \\
\text { ant) in diets of male and female aged birds of }\end{array}$ \\
\hline
\end{tabular}

Key words: grape pomace, vit. E, productive performance, semen quality. 


\section{INTRODUCTION}

The free radical theory of aging is one of the most popular theories of aging based on age associated with increasing free radical and the later doing lipid peroxidation which is leading to excessive loss in membrane fluidity, reduction in membrane potential and increase it's permeability to ions which leading to cellular damage and thereby decreased physiological performance and increased susceptibility to diseases $(\mathrm{Yu}$ and Yang, 1996), for example, Alzheimer's disease and Parkinson's disease which contributes to increasing in lipid peroxidation and decreased antioxidants in the central nervous system during aging advanced (Spiteller, 2001 and Schipper, 2004). Activities of both antioxidant enzymes such as superoxide dismutase, glutathione peroxidase, catalase and non-enzymic antioxidants like grape seed extract-supplemented, vitamin $\mathrm{E}$ and vitamin $\mathrm{C}$, had significant potential to decrease lipid peroxidation in striatum, cerebral cortex, spinal cord and the hippocampus regions of aged rats when compared to young rats (Balu et al., 2005).

Research for new bioefficient antioxidants has focused on antioxidants from natural sources (plants) like grape pomace to respect the consumer concerns over safety from toxicity, easily obtained from natural sources and efficiently prevent lipid oxidation in food products compared to Vitamin $\mathrm{E}$ which consider antioxidant from synthetic origin with its limited 1) bioefficiency when polyunsaturated fatty acids in bird's diet is too high; 2) potential antioxidant action and 3) homogeneous spread between tissues. (Mukai et al., 1993, Allard et al., 1997 and Brenes et al., 2008).

Grape pomace which collected during stems isolation, grape crushing, and pressing for skins, seeds, and lees (Llobera and Can ellas, 2007), is rich in a wide range of polyphenols (Bonilla et al., 1999; Alonso et al., 2002; Torres et al., 2002). and had many properties, including antioxidant, antifungal, antiviral, anti-inflammatory and anticancer activities, prevention of atherosclerosis, platelet aggregation inhibiting, improvement of ischaemic cardiovascular disease, metal chelating properties (Yamakoshi et al., 1999; Cos et al., 2003) moreover, antimicrobial potential which consequently, may positively influence growth (Lichovnikova et al., 2015). Previous studies found an increase in the antioxidant activity of broiler's diet, excreta, and meat due to dietary administration of grape pomace concentrations (Gon ${ }^{\sim}$ I et al. 2007 and Brenes et al. 2008). And thereby comparative study is required concerning the effects of different sources of antioxidants on aged birds. Therefore, the objective of the present study was to compare between grape pomace at levels $1,2,3$, and $4 \%$ as a natural source of antioxidant and $150 \mathrm{mg}$ vit E./kg diet as a synthetic source on some productive, reproductive and physiological performance of male and female aged Inshas strain chickens.

\section{MATERIALS AND METHODS}

This experiment was executed at Inshas Poultry breeding Station, Animal Production Research Institute, Agricultural Research Center. 
grape pomace, vit. E, productive performance, semen quality.

\section{Experimental design}

A total number of 198 Inshas strain birds (180 laying hens and 18 cocks) 48-wksold were used in this experiment up to 60 wks of age. All birds were individually weighed and randomly divided into six equal experimental groups (thirty laying hens and three cocks of each) with three replicates (ten laying hens and one cock each) with almost similar initial average body weight. The $1^{\text {st }}$ group was fed the basal diet without

supplementation (control group), while $2^{\text {nd }}, 3^{\text {rd }}$ and $4^{\text {th }}$ and $5^{\text {th }}$ were fed on the basal diet supplemented with 1,2,3 and $4 \%$ grape pomace respectively and the 6 th group was fed the basal diet supplemented with $150 \mathrm{mg}$ vit.E/ $\mathrm{kg}$ diet.

\section{Management and feeding:}

All birds were kept under the same managerial hygienic and environmental conditions. Birds were exposed to 16 hours light/day up to the end of experiment period (60 wks of age). Feeding was on layer's diet which contains $(16.5 \% \mathrm{CP}$ and $2700 \mathrm{Kcal})$ according to NRC (1994). The composition and calculated analysis of the basal diet are shown in table (1). Water was provided for ad libitum consumption during the experimental period.

Chemical composition of grape pomace and vit.E were determined according to (A.O.A.C., 1990) in Table (2).

\section{Measurements:-}

\section{Laying performance traits:}

Birds body weights were individually recorded at the beginning (48 weeks of age) and the end of the experiment (60 weeks of age). Feed intake (FI, g diet/hen/day) and feed conversion ratio (FCR, g feed/g egg mass/day), and egg production (\%), egg weight $(\mathrm{EW}, \mathrm{g})$ and egg mass (EM, g/90 day) was calculated as (number of eggs $x$ egg weight) in replicate basis at the end of each month from (48 up to $60 \mathrm{wks}$ ) of age.

Blood biochemical analysis:

At the end of experiment (60 weeks of age), blood samples were collected. Five hens from each treatment group were randomly selected for taking blood samples $(3 \mathrm{~cm} / \mathrm{hen})$ from the right brachial vein using a sterilized syringe; in heparinized test tubes then centrifuged at $3000 \mathrm{rpm}$ for 20 minutes. The separated plasma was stored at $-20^{\circ} \mathrm{C}$ for until being assayed for plasma superoxide dismutase (SOD), glutathione peroxidase (GPX), testosterone and Iron (Fe) concentrations according to the manufacture recommendations of commercial kits.

\section{Semen quality:}

Semen samples were randomly collected from eighteen cocks (three cocks of each treatment) at 60 weeks of age using the massage method. Semen samples were checked for the following characteristics, according to Kalamah et al. (2000).

1-The ejaculate volume was determined to the nearest $0.01 \mathrm{ml}$. using $1.00 \mathrm{ml}$. tuberculin syringe.

2-Mass motility score (from 1 to 5 grades).

3-Percentage of live and abnormal sperm was determined after staining with eosine and nigrosine.

4-Sperm concentration was determined by using Thomes - Zeis haemocytometer. 5-Total sperm/ejaculate $\times 10^{9}=$ (ejaculate volume $\mathrm{x}$ sperm concentration). 
6-Total abnormal sperm/ejaculate x $10^{9}$ $=($ abnormal sperm $\% \mathrm{x}$ total sperm/ejaculate /100).

7-Total live sperm/ejaculate $\times 10^{9}=($ live sperm $\% \mathrm{x}$ total sperm/ejaculate /100).

\section{Fertility and hatchability percentages:}

At 60 weeks of age, each treatment contained 3 replicates, each replicate contains of 10 hens and 1 cock. The cocks and hens were placed on the floor and supplied with the same previous treatments. Eggs from each treatment were daily collected for two weeks, and then incubated to determine fertility and hatchability percentages of both fertile and total eggs set.

\section{Statistical analysis:}

Data were analyzed by one-way analysis of variance using SAS (2000). Differences among means were determined by using Duncan's multiple range test (Duncan, 1955). The percentage values were transferred to percentage angle using arcsine equation before analyzed by statistical analysis, and then actual means are presented. The following model was used:

$Y i j=G+T i+e i j$.

Where, Yij = observation for each dependent variable; $\mathrm{G}=$ General mean;

$\mathrm{Ti}=$ Treatment effects $(\mathrm{i}=1,2 \ldots$ and 5$)$; eij $=$ Random error.

\section{RESULTS}

Productive performance traits:

Body weight, body weight gain, total feed intake, feed conversion, egg number, egg production percentage, egg weight and egg mass of Inshas laying hens during the period from 48 to 60 weeks of age affected by dietary supplementation of grape pomace or vit. $\mathrm{E}$ are presented in Table (3). Adding different levels of grape pomace (except the level of $1 \%$ ) or vit. E to laying hen's diet increased hen productive performance significantly $(\mathrm{P} \leq 0.05)$ in terms of egg number, egg production percentage and egg mass and without significant effects on body weight gain and egg weight compared to control group (T1) although, total feed intake had comparable values (slight increase) among all experimental groups compared to control group (T1). Moreover, values of levels 3 and $4 \%$ grape pomace were higher than values of vit. E for traits feed conversion, egg number, egg production percentage and egg mass and the differences were significantly $(\mathrm{P} \leq 0.05)$ for the level of $4 \%$ grape pomace only.

\section{physiological performance traits:}

I) Blood biochemical analysis:

Data of some blood constituents of laying hens affected by experimental treatments are presented in Table (4). Adding grape pomace or vit.E to laying hens diet significantly $(\mathrm{P} \leq 0.05)$ increased plasma superoxide dismutase, glutathione peroxidase and testosterone concentrations comparing to untreated group (control) except $1 \%$ grape pomace for plasma testosterone only and the highest level of plasma superoxide dismutase, glutathione peroxidase and testosterone was recorded for the highest level of $4 \%$ grape pomace (T5) in laying hens diet. While, adding different levels of grape pomace (T2, T3, T4 and T5) or vit. E (T6) to laying hens diet did not significantly affect plasma Iron $(\mathrm{Fe})$ concentrations compared to the control group (T1) but, slight gradual decrease (without bad effects on performance traits studied) was observed with increasing dietary levels of grape pomace. 
grape pomace, vit. E, productive performance, semen quality.

\section{II) Semen quality:}

Data of the semen physical characteristics at 60 wks of age affected by dietary supplementation of grape pomace or vit. E are shown in Table (5). Supplementation of grape pomace to cock's diet at different levels or vit. E caused significant $(\mathrm{P} \leq 0.05)$ effect on all semen physical characteristics studied except semen $\mathrm{pH}$ at 60 wks of age. The values of ejaculate volume (E.V), sperm motility (S.M), live sperm percentage (L.S\%), sperm concentration (S.C), total sperm per ejaculate (TS/E) and total live sperm per ejaculate (TLS/E) were increased but abnormal sperm percentage $(\mathrm{Ab} . \mathrm{S} \%)$ and total abnormal sperm per ejaculate (TAbS/E) were decreased as the levels of grape pomace in cocks diet increased compared to cocks of control group (T1). The highest level of grape pomace (T5) exhibited the best values in all semen physical characteristics studied with significant $(\mathrm{P} \leq 0.05) \quad$ differences compared to vit. E (T6) and control (T1) groups for traits sperm motility, live sperm percentage, sperm concentration, total sperm per ejaculate, total live sperm per ejaculate and total abnormal sperm per ejaculate and significant $(\mathrm{P} \leq 0.05)$ differences compared to control group only in ejaculate volume and abnormal sperm percentage.

\section{III) Fertility and Hatchability percentage:}

Fertility and hatchability percentage of both total and fertile eggs of Inshas laying hens affected by dietary supplementation of grape pomace or vit. E at 60 wks of age are presented in Table (6). In general the values of fertility and hatchability percentage of both total and fertile eggs were increased gradually by increasing dietary grape pomace levels. The highest values with significant $(\mathrm{P} \leq 0.05)$ differences for fertility and hatchability percentage of both total and fertile eggs were recorded for the highest level of grape pomace (T5) compared to vit. E (T6) and control (T1) groups.

DISCUSSION

Adding different levels of grape pomace (except the level of 1\%) or vit. E to laying hen's diet increased hen productive performance significantly $(\mathrm{P} \leq 0.05)$ in terms of egg number, egg production percentage and egg mass and without significant effects on body weight gain and egg weight compared to control group (T1) although, total feed intake had comparable values (slight increase) among all experimental groups compared to control group (T1) could be attributed to better utilization and absorption of the nutrients in the gastro-intestinal tract, which leading to better feed conversion efficiency and thereby increasing hen performance which may be through three probable reasons; 1) grape pomace increased villus height: crypt depth ratio, this lengthening of the villus result in an increase in absorptive surface area which lead to increasing nutrient absorption thus, enhancing feed conversion and hen performance (Viveros et al. 2011). 2) phenolic compounds of grape pomace had potential to decrease ileal E. coli populations, coliforms, Propionibacteria, Bacteroides, and Clostridia because it decrease the adhesion of these bacteria to cells of the intestinal tract $\left(\mathrm{O}^{\prime \prime}\right.$ zkan et al., 2004 and Papadopoulou et al., 2005), through two possible mechanisms, First) the outer cell membrane or cytoplasmic membrane of a bacterium is essentially composed of a phospholipid bilayer and 


\section{A.K. Alm El-Dein et al.}

proteins which is the major site of
interaction with antimicrobial compounds, gallic acid esters in epicatechin and epigallocatechin gallate (phenolic compounds of grape pomace) have bad effects on the lipid bilayer membrane which results in loss of cell structure and function, thus leading to bacterial death (Perumalla and Hettiarachchy, 2011). And Second) major phenolic constituents in grape pomace like epicatechin, caffeic acid, benzoic acid and syringic acid alter the osmotic pressure of the bacteria cell, thereby rupture the cytoplasmic membrane causing leakage of cell constituents leading to bacterial death (Sivarooban et al. 2008). On the other hand, these phenolic compounds of grape pomace had a positive effect on the content of Lactobacillus and Bifidobacteria in the lower part of the ileum because Lactobacillus has the ability to metabolize phenolic compounds as nutritional substrates, thus supplying energy to cells and positively affecting the bacterial metabolism, these positive alter in intestinal bacteria composition considered a good environment for better absorption of nutrients in the intestine lumen (García-Ruíz et al. 2008). This concept is confirmed by (Viveros et al. 2011) who concluded that dietary polyphenols compounds in grape byproducts modify gut morphology and increase the biodiversity of intestinal bacteria in broilers. And 3) Both grape pomace and vit. E had potent antioxidant activity through the following mechanisms First) protecting molecules of nutrients from possible oxidative damage during digestion by scavenging the free radicals through modulates the expression of genes that are required by free radical signaling. (Frank, 2005; Silbergberg et al., 2006; Gon ${ }^{\sim}$ et al., 2007). and thereby allowing to these nutrients for more digestion thus increasing bird's productivity; Second) preserving the intestinal epithelium from potential oxidative damage caused by dietary factors or bacterial metabolism (Scalbert and Williamson, 2000; Gon i and Serrano, 2005). And thereby, leading to improving the antioxidant status of tissue thus, reflect on better utilization and absorption of the nutrients in the gastro-intestinal tract, which in accordance with (Gon ${ }^{\sim} \mathrm{i}$ and Serrano, 2005) who found that inclusion of grape flavonoids causes a diminution of tissue lipid peroxidation and considerable antioxidant activity within the large intestine and Third) protect the liver cells from lipid peroxidation of it's cell membrane thus liver cells continues doing its function of synthesis the very low density lipoprotein and vitellogenin which consider egg yolk precursors and increasing deposition of them during yolk formation (Bollengier-Lee et al., 1998 and 1999 and Puthpon-Gsiriporn et al., 2001), thereby increasing egg production, which in line with (Rodrigo et al., 2002, 2005), who found improving of the antioxidant defense potential in kidney and liver of rats by flavonol rich red wine Forth) oxidative processes leading to conformational modifications of protein leading to dietary protein resistance to digestion. Consequently, the presence of anti-oxidants (vit.E) could partially interfere with oxidative protein denaturation and thereby improving its digestibility thus reflect on hen productivity (Ciftci et al., 2005), which 
grape pomace, vit. E, productive performance, semen quality.

parallel with (Brenes et al., 2010), who illustrated that adding graded concentration of grape seed extract to broiler diet caused a significant increase of ileal protein digestibility (up to $4 \%$; linear effect) at 21 days of age compared to birds which fed control diet. Our results are in harmony with the finding of (Wang et al., 2008), who demonstrated that grape seed proanthocyanidin extract in broiler's diet had an antioxidant effect to improve the performance of broiler chickens.

Concerning to feed intake, the slight increase in total feed intake for any level of grape pomace compared to control group may be because the phenolic compounds in grape pomace like tannin and proanthocyanidin etc. had appetite stimulating effect (Tekeli et al., 2014).

Regarding to treatments comparison, values of levels 3 and $4 \%$ grape pomace were higher than values of vit. $\mathrm{E}$ for traits feed conversion, egg number, egg production percentage and egg mass, but the values exhibited significant $(\mathrm{P} \leq 0.05)$ differences for the level of $4 \%$ grape pomace only may be because the antioxidant potential (free radical scavenging capability) of grape seed is fifty and twenty fold greater than vitamins $\mathrm{C}$ and $\mathrm{E}$ respectively, caused from increased levels of polyphenols proanthocyanidins and oligomers of flavan-3-ol units, especially catechin and epicatechin present in grape pomace (Shi et al., 2003 and Yilmaz and Toledo, 2004). These results added credence to the conclusion of (Gon I, et al., 2007), who found that the activity of antioxidant in vit. E and grape pomace diets exhibited significantly higher scavenging free radical capacity 3.4 and 6.6 times than control diets using ABTS method $\{2,2-$ azinobis (3-ethilenzotiazolin)-6sulfonate\}respectively Moreover, antioxidant activity of grape pomace in diet and ileal content up to 3.3 and 2.0 times compared to vit. E respectively (Brenes et al., 2008).

As regard to some blood plasma measurements, adding grape pomace to laying hens diet significantly $(\mathrm{P} \leq 0.05)$ increased plasma superoxide dismutase, glutathione peroxidase and testosterone concentrations but slight gradual decrease plasma Iron $(\mathrm{Fe})$ concentrations (without bad effects on performance traits) with increasing dietary levels of grape pomace comparing to untreated group (control) may be because procyanidins in grape pomace had potential to affect the gene expression of antioxidant enzymes by interacting with element promoter in DNA (Puiggross et al., 2005), thus leading to increasing both superoxide dismutase which scavenging superoxide radicals and glutathione peroxidase which react directly with reactive oxygen species ( ROS), and the later widely produced by cell metabolism and react with double bonds of polyunsaturated fatty acids to yield lipid hydro peroxides thus cause tissue damage (Halliwell and Gutteridge 1984 and Arthur, 2000). For this, these enzymes considered the enzymatic defense system against free radicals and protecting cells against oxidative damage (Vertuani, et al., 2004) also, reflect on increasing plasma testosterone concentrations because reduced the levels of enzymatic and nonenzymatic antioxidants in Leydig cells (testis's interstitial cells), resulted in decrease the secretion of testosterone (Cao et al., 2004). The slight gradual 
decrease plasma Iron concentrations (without bad effects on performance traits) may partially explain the antioxidant activity of grape pomace (Chamorro, et al., 2013). Our findings paralleled with earlier work by (Priya, et al., 2012), who found that testosterone concentration increased by supplementing $1 \%$ grape seed powder to broiler breeder's diet from 32 to 37 weeks of age during the second and third week of treatment period, which significantly declined from the first week of post treatment period.

Respecting to semen quality, increasing sperm motility by dietary supplementation of grape pomace or vit. E may be because 1) grape pomace facilitated glucose transport by GLUT -5 gene expression in sperm (Ajit, 2007). 2) Increase glutathione peroxidase activity by dietary supplementation as mentioned above enhanced the protection of polyunsaturated fatty acids (PUFA) component in cock's semen against lipid peroxidation. These PUFA exist with large amounts in sperm cells and allow them to maintain flexibility relating to motility, (Surai et al. 2001) and 3) vit.E decreases semen homocysteine which is a defective amino acid formed from demethylation of methionine, increasing homocysteine blocks intra-cellular protein-carboxyl methylation reactions results in inhibition of sperm motility (Sonmez et al., 2007). Our results are similar to the conclusions drawn by Lin et al. (2005) who found that increasing level of vit.E from 40 to $160 \mathrm{mg} / \mathrm{kg}$ diet for Taiwan native cocks at 39 week of age significantly improving semen traits, particularly sperm livability and motility. Significant $\quad(\mathrm{P} \leq 0.05) \quad$ decrease of abnormal sperm percentage and increase sperm concentration by dietary supplementation of grape pomace or vit. E compared to control group may be due to the ability of grape pomace or vit. $\mathrm{E}$ as antioxidants to resist the oxidative DNA damage and genetic alterations in the spermatozoa thus decrease abnormal sperm percentage (Bagachi et al., 1997). Moreover, grape pomace or vit. E increase testosterone hormone as mentioned in our results (Table 4), and the latter is required to complete meiosis and spermatids differentiation (Sharpe, 1994), therefore increasing sperm production and concentration (Fernandez, 2008). This concept is confirmed by Jianguo and Zhinian, (1990) who said that testosterone concentration in serum was positively correlated with semen quality.

As regard to fertility and hatchability traits, values of fertility and hatchability percentage of both total and fertile eggs were increased by dietary grape pomace and vit.E compared to control group may be because grape pomace and vit.E increase sperm motility as mentioned above (table 5) and the motility is essential for sperm to traverse the vagina and reach the sperm storage tubules which is important for increasing fertility moreover, reduce lipid peroxidation in seminal plasma through reducing dexamethasone thus maintains an adequate viability of sperm which helping to complete the fertilization process (Eid et al., 2006). Also, grape pomace and vit.E through improving antioxidant status resulted in improving hatchability because oxidative metabolism increases during embryo development at hatchability process especially in the last 
grape pomace, vit. $E$, productive performance, semen quality.

few days before hatch, due to normal respiration related to embryo growth results in increasing the production of free radicals that doing lipid peroxidation leading to tissue damage and hatchability decline (Freeman and Vince, 1974). This concept is confirmed by (Benzie, 2003) who said that although Oxygen is vital for most organisms but, simultaneously, considered a damage key for biological sites and this damage is met by antioxidants substances.

\section{CONCLUSION}

Improving female egg production and male fertility of aged birds are the major goals of scientists. Supplementation of the highest level of grape pomace (4\%) were the most effective for all traits studied with significant $(\mathrm{P} \leq 0.05)$ values for some hen productive performance traits (feed conversion, egg number, egg production percentage and egg mass), some blood biochemical analysis (plasma superoxide dismutase, glutathione peroxidase and testosterone), some semen quality traits (sperm motility, live sperm percentage, sperm concentration, total sperm per ejaculate, total live sperm per ejaculate and total abnormal sperm per ejaculate) and fertility and hatchability traits (fertility and hatchability percentage of both total and fertile eggs) compared to vit. E group. On the basis of these findings, we concluded a potential use of $4 \%$ grape pomace (natural source of antioxidant) as alternative to vit. E (synthetic source of antioxidant) in diets of male and female aged birds of Inshas strain, and deserves serious attention through future researches to get better understanding the role of grape pomace in promoting productive and reproductive performance of aged birds and their implications in human health before arriving at final conclusions. 
Table (1): Composition and calculated analysis of the experimental basal diet.

\begin{tabular}{|l|l|}
\hline \multicolumn{1}{|c|}{ Ingredients } & Percentage (\%) \\
\hline Yellow corn & 61.57 \\
Soya bean 44\% & 17.00 \\
Wheat bran & 6.70 \\
Corn gluten 60\% & 4.50 \\
Di Ca Phosphate & 1.39 \\
Lime stone & 8.16 \\
Salt & 0.37 \\
*Premix & 0.30 \\
DL Methionine & 0.01 \\
Total & 100.00 \\
\hline Calculated values (\%) ** & \\
\hline Crude protein & 16.5 \\
Metabolizable energy (M.E.) & 2700 \\
Crude fiber (C. F.) & 3.5 \\
Ether extract & 3.0 \\
Calcium & 3.4 \\
Available Phosphorous & 0.40 \\
Total Phosphorous & 0.60 \\
Sodium & 0.16 \\
Lysine & 0.70 \\
Methionine & 0.34 \\
Methionine \& cysteine & 0.62 \\
\hline
\end{tabular}

*premix added to the $1 \mathrm{~kg}$ of diet including Vit.A 10000 I.U; vit. D3 2000 I.U; vit. E $15 \mathrm{mg}$; vit. K3 $1 \mu \mathrm{g}$; vit B1 1mg; vit. B2 5mg; vit. B12 $10 \mu \mathrm{g}$; vit B6 $1.5 \mathrm{mg}$; Niacin 30mg; Pantothenic acid 10mg; folic acid 1mg; Biotin $50 \mathrm{mg}$; choline 300 $\mathrm{mg}$; zinc $50 \mathrm{mg}$; copper $4 \mathrm{mg}$; iodine $0.3 \mathrm{mg}$; iron $30 \mathrm{mg}$; selenium $0.1 \mathrm{mg}$; manganese $60 \mathrm{mg}$; cobalt $0.1 \mathrm{mg}$ and carrier $\mathrm{CaCo} 3$ up to $1 \mathrm{~kg}$.

** Calculated according to NRC. (1994).

Table (2): Chemical composition of grape pomace \% (on Dry Matter basis).

\begin{tabular}{|c|c|c|c|c|c|}
\hline Item & Ash & OM & CP & EE & CF \\
\hline grape pomace & 23.70 & 76.30 & 13.9 & 9.14 & 14.26 \\
\hline
\end{tabular}

(OM=Organic Matter); ( $\mathrm{CP}=$ Crude Protein); ( $\mathrm{EE}=$ Ether Extract); $(\mathrm{CF}=$ Crude Fiber). 
Table (3): Effect of dietary grape pomace and Vit.E supplementation on the performance of Inshas laying hens during the experimental period.

\begin{tabular}{|c|c|c|c|c|c|c|c|}
\hline Item & T1 & T2 & T3 & T4 & T5 & T6 & SEM \\
\hline Initial body weight (g) & 1498.11 & 1506.43 & 1487.31 & $14-91.54$ & 1484.92 & 1509.04 & 19.11 \\
\hline Final body weight (g) & 1569.09 & 1573.61 & 1581.52 & 1588.73 & 1586.55 & 1574.96 & 18.19 \\
\hline body weight gain (g) & 70.98 & 67.18 & 94.21 & 97.19 & 101.63 & 65.92 & 21.24 \\
\hline Total feed intake (g/hen/period) & 8112.58 & 8113.22 & 8124.81 & 8145.28 & 8169.47 & 8139.83 & 31.18 \\
\hline Feed conversion (g feed/g egg & $3.48^{\mathrm{a}}$ & $3.34^{\mathrm{ab}}$ & $3.23^{\mathrm{bc}}$ & $3.14^{\mathrm{c}}$ & $2.94^{\mathrm{d}}$ & $3.24^{\mathrm{bc}}$ & 0.13 \\
\hline $\begin{array}{l}\text { mass) } \\
\text { Egg number (egg) }\end{array}$ & $46.32^{d}$ & $48.38^{\mathrm{cd}}$ & $49.97 \mathrm{bc}$ & $51.23^{b}$ & $54.87^{\mathrm{a}}$ & $49.85^{\mathrm{bc}}$ & 1.13 \\
\hline Egg production (\%) & $55.13^{\mathrm{d}}$ & $57.60^{\mathrm{cd}}$ & $59.48^{b c}$ & $60.98^{b}$ & $65.32^{\mathrm{a}}$ & $59.35^{\mathrm{bc}}$ & 1.24 \\
\hline Egg weigh (g/day) & 50.25 & 50.33 & 50.36 & 50.61 & 50.64 & 50.46 & 0.25 \\
\hline Egg mass (g/period) & $2327.31^{d}$ & $2434.23^{\mathrm{cd}}$ & $\begin{array}{l}2516.67 \\
\mathrm{bc}\end{array}$ & $2592.18^{b}$ & $2778.39^{\mathrm{a}}$ & $2515.14^{b c}$ & 61.21 \\
\hline
\end{tabular}

a, b.... Means within each row have no similar letter(s) are significantly different $(\mathrm{P} \leq 0.05)$.

$\mathrm{T} 1=$ Control; $\quad \mathrm{T} 2=1 \%$ grape pomace; $\quad \mathrm{T} 3=2 \%$ grape pomace;

$\mathrm{T} 4=3 \%$ grape pomace; $\quad \mathrm{T} 5=4 \%$ grape pomace; $\quad \mathrm{T} 6=150 \mathrm{mg}$ vit.E $/ \mathrm{kg}$ diet 
Table (4): Effect of dietary grape pomace and Vit.E supplementation on some blood plasma measurements of Inshas laying hens at 60 weeks of age.

\begin{tabular}{|l|l|l|l|l|l|l|l|}
\hline \multicolumn{1}{|c|}{ Item } & \multicolumn{1}{c|}{ T1 } & \multicolumn{1}{c|}{ T2 } & \multicolumn{1}{c|}{ T3 } & \multicolumn{1}{c|}{ T4 } & \multicolumn{1}{c|}{ T5 } & \multicolumn{1}{c|}{ T6 } & SEM \\
\hline Plasma SOD (U/mL) & $126.47^{\mathrm{e}}$ & $132.11^{\mathrm{d}}$ & $135.42^{\mathrm{cd}}$ & $137.87^{\mathrm{bc}}$ & $143.74^{\mathrm{a}}$ & $136.51^{\mathrm{bc}}$ & 0.21 \\
Plasma GSH-Px (U/mL) & $163.34^{\mathrm{d}}$ & $169.47^{\mathrm{c}}$ & $172.14^{\mathrm{bc}}$ & $174.76^{\mathrm{ab}}$ & $178.01^{\mathrm{a}}$ & $171.98^{\mathrm{bc}}$ & 0.48 \\
Testosterone (ng/ml) & $2.36^{\mathrm{d}}$ & $2.59^{\mathrm{cd}}$ & $2.97^{\mathrm{bc}}$ & $3.22^{\mathrm{ab}}$ & $3.68^{\mathrm{a}}$ & $2.98^{\mathrm{bc}}$ & 0.32 \\
Plasma Fe (mg/dl) & 311.60 & 310.90 & 309.20 & 307.60 & 305.80 & 309.90 & 4.70 \\
\hline
\end{tabular}

a, b... Means within each row have no similar letter(s) are significantly different $(\mathrm{P} \leq 0.05)$.

$\mathrm{T} 1=$ Control; $\quad \mathrm{T} 2=1 \%$ grape pomace; $\quad \mathrm{T} 3=2 \%$ grape pomace;

$\mathrm{T} 4=3 \%$ grape pomace; $\mathrm{T} 5=4 \%$ grape pomace; $\quad \mathrm{T} 6=150 \mathrm{mg}$ vit.E $/ \mathrm{kg}$ diet

$\mathrm{Fe}=$ Iron; $\quad \mathrm{SOD}=$ superoxide dismutase; GSH-Px = glutathione peroxidase

$\approx \quad$ Table (5): Effect of dietary grape pomace and Vit.E supplementation on semen quality traits of Inshas cocks at 60 weeks of age.

\begin{tabular}{|c|c|c|c|c|c|c|c|}
\hline Item & T1 & T2 & T3 & T4 & T5 & T6 & SEM \\
\hline Ejaculate volume (ml) & $0.35^{\mathrm{b}}$ & $0.37^{\mathrm{b}}$ & $0.40^{\mathrm{a}}$ & $0.41^{\mathrm{a}}$ & $0.42^{\mathrm{a}}$ & $0.40^{\mathrm{a}}$ & 0.03 \\
\hline Semen pH & 7.61 & 7.54 & 7.68 & 7.65 & 7.59 & 7.62 & 0.28 \\
\hline Sperm motility (1-5) & $2.53^{\mathrm{d}}$ & $2.91^{\mathrm{cd}}$ & $3.12^{\mathrm{c}}$ & $3.77^{\mathrm{ab}}$ & $4.03^{\mathrm{a}}$ & $3.41^{\mathrm{bc}}$ & 0.32 \\
\hline Live sperm \% & $74.51^{\mathrm{d}}$ & $78.33^{\mathrm{c}}$ & $81.96^{\mathrm{b}}$ & $82.82^{b}$ & $88.14^{\mathrm{a}}$ & $81.97^{\mathrm{b}}$ & 1.83 \\
\hline Abnormal sperm \% & $14.26^{\mathrm{a}}$ & $12.41^{b c}$ & $11.32^{\mathrm{cd}}$ & $10.37^{\mathrm{de}}$ & $9.54^{\mathrm{e}}$ & $10.88^{\mathrm{de}}$ & 1.12 \\
\hline Sperm concentration $\left(x \mathbf{1 0}^{9}\right)$ & $2.78^{\mathrm{c}}$ & $3.12^{\mathrm{b}}$ & $3.31^{\mathrm{b}}$ & $3.42^{\mathrm{b}}$ & $3.97^{\mathrm{a}}$ & $3.38^{\mathrm{b}}$ & 0.31 \\
\hline Total sperm/ejaculate & $0.97^{\mathrm{d}}$ & $1.15^{\mathrm{c}}$ & $1.33^{\mathrm{b}}$ & $1.40^{\mathrm{b}}$ & $1.67^{\mathrm{a}}$ & $1.35^{\mathrm{b}}$ & 0.15 \\
\hline Total live sperm/ejaculate & $0.72^{\mathrm{d}}$ & $0.90^{\mathrm{c}}$ & $1.09^{\mathrm{b}}$ & $1.16^{\mathrm{b}}$ & $1.47^{\mathrm{a}}$ & $1.11^{\mathrm{b}}$ & 0.21 \\
\hline Total abnormal sperm/ejaculate & $0.148^{\mathrm{a}}$ & $0.145^{\mathrm{a}}$ & $0.144^{\mathrm{ab}}$ & $0.140^{\mathrm{bc}}$ & $0.138^{\mathrm{c}}$ & $0.144^{\mathrm{ab}}$ & 0.031 \\
\hline
\end{tabular}

a, b... Means within each row have no similar letter(s) are significantly different $(\mathrm{P} \leq 0.05)$.

$\mathrm{T} 1=$ Control; $\quad \mathrm{T} 2=1 \%$ grape pomace; $\quad \mathrm{T} 3=2 \%$ grape pomace;

$\mathrm{T} 4=3 \%$ grape pomace; $\quad \mathrm{T} 5=4 \%$ grape pomace; $\quad \mathrm{T} 6=150 \mathrm{mg}$ vit.E $/ \mathrm{kg}$ diet 
Table (6): Effect of dietary grape pomace and Vit.E on fertility and hatchability\% of Inshas laying hens at 60 wks of age.

\begin{tabular}{|l|c|c|c|}
\hline \multicolumn{1}{|c|}{ Classification } & Fertility\% & Hatchability of total eggs (\%) & Hatchability of fertile eggs (\%) \\
\hline T1 & $81.2^{\mathrm{c}}$ & $63.4^{\mathrm{d}}$ & $74.1^{\mathrm{d}}$ \\
T2 & $82.4^{\mathrm{c}}$ & $65.9^{\mathrm{d}}$ & $76.7^{\mathrm{d}}$ \\
T3 & $83.9^{\mathrm{c}}$ & $69.8^{\mathrm{c}}$ & $80.0^{\mathrm{c}}$ \\
T4 & $88.5^{\mathrm{ab}}$ & $74.6^{\mathrm{b}}$ & $849^{\mathrm{b}}$ \\
T5 & $91.3^{\mathrm{a}}$ & $81.2^{\mathrm{a}}$ & $90.8^{\mathrm{a}}$ \\
T6 & $85.8^{\mathrm{b}}$ & $70.3^{\mathrm{c}}$ & $81.2^{\mathrm{bc}}$ \\
SEM & 1.04 & 1.22 & 1.08 \\
\hline
\end{tabular}

a, b....Means within each column within each trait have no similar letter(s) are significantly different $(\mathrm{P} \leq 0.05)$.

$\begin{array}{lll}\mathrm{T} 1=\mathrm{Control} ; & \mathrm{T} 2=1 \% \text { grape pomace; } & \mathrm{T} 3=2 \% \text { grape pomace; } \\ \stackrel{\mathrm{T}}{ } \mathrm{S}=3 \% \text { grape pomace; } & \mathrm{T} 5=4 \% \text { grape pomace; } & \mathrm{T} 6=150 \mathrm{mg} \text { vit.E } \mathrm{kg} \text { diet }\end{array}$ 


\section{REFERENCES}

A.O.A.C. 1990. Official methods of analysis, Association of official analytical chemists. 15th Ed., Washington, D.C., U.S.A.

Ajit, V. 2007. Double- blind comparative trial of herbomineral antioxidant formulation with ubiquinone in oligoasthenospermia.

Lancet.Infect.Dis., 7:1057-1058.

Allard, J.; Kurian, R.; Aghdassi, E.; Muggli, R. and Royall. D. 1997. Lipid peroxidation during n-3 fatty acid and vitamin $\mathrm{E}$ supplementation in humans. Lipids 32:535-541.

Alonso, A.M.; Guille’n, D.A.; Barroso, C.G.; Puertas, B. and Garci'a, A. 2002. Determination of antioxidant activity of wine byproducts and its correlation with polyphenolic content. J. Agric. Food Chem. 50:5832-5836.

Arthur, J. R. 2000. The glutathione peroxidases. Cell. Mol. Life Sci., 57: 1825-1835.

Bagachi D.; Garg, A. ; Krohn, R.; Bagachi, M.; Tran, M. and Stohs, S. 1997. Oxygen free radical scavenging abilities of vitamin $\mathrm{C}$ and $\mathrm{E}$ and grape seed proanthocynidin extract in vitro. Res. Commun. Mol. Pathol. Pharmacol., 95: 179-90.

Balu, M.; Sangeetha, P.; Haripriya, D. and Panneerselvam, C. 2005. Rejuvenation of antioxidant system in central nervous system of aged rats by grape seed extract. Neuroscience Letters, 383: 295-300.

Benzie, I.F.F. 2003. Evolution of dietary antioxidants. Review. Comparative Biochemistry and Physiology, Part A 136: 113-126.

Bollengier-Lee, S.; Mitcliell, M.A.; Utom, D.B.; Williams, P.E. and
Whitehead, C.C. 1998. Influence of high dietary vitamin E supplementation on egg production and plasma characteristics in hens subjected to heat stress. British Poultry Science, 39:106-112.

Bollengier-Lee, S.; Williams, P.E. and Whitehead, C.C. 1999. Optimal dietary concentration of vitamin $\mathrm{E}$ for alleviating the effect of heat stress on egg production in laying hens. British Poultry Science, 40:102-107.

Bonilla, F.; Mayen, M.; Me'rida, J. and Medina, M. 1999. Extraction of phenolic compounds from red grape marc for use as food lipid antioxidants. Food Chemistry, 66:209-215.

Brenes, A.; Viveros, A.; Gon ${ }^{\sim}$ I, I.; Centeno, C.; Sa' yago-Ayerdi, S.G.; Arija, I. and Saura-Calixto, F. 2008. Effect of grape pomace concentrate and vitamin $\mathrm{E}$ on digestibility of polyphenols and antioxidant activity in chickens. Poultry Science 87,307-316.

Brenes, A.; Viveros, A.; Goñi, I.; Centeno, C.; Saura-Calixto, F. and Arija, I. 2010. Effect of grape seed extract on growth performance, protein and polyphenol digestibilities, and antioxidant activity in chickens. Spanish Journal of Agricultural Research, 8(2): 326-333.

Cao, L.; Leer Suchetha, S. and Azhar, S. 2004. Aging alters the functional expression of enzymatic antioxidant defense systems in testicular rat Leydig cell. J. Steroid Biochem. Mol. Biol., 88: 61-67.

Chamorro, S.; Viveros, A.; Centeno, C.; Romero, C.; Arija, I. and Brenes, A. 2013. Effects of dietary grape seed extract on growth performance, amino acid digestibility 
grape pomace, vit. E, productive performance, semen quality.

and plasma lipids and mineral content in broiler chicks. Animal, 7(4): 555561.

Ciftci, M.; Nihat, O.E. and Guler, T. 2005. Effects of vitamin $\mathrm{E}$ and vitamin $\mathrm{C}$ dietary supplementation on egg production and egg quality of laying hens exposed to a chronic heat stress. Revue Med. Vet., 156: 107-111.

Cos, P.; De Bruyne, N.; Hermans, S.; Apers, D.; Berghe, V. and Vlietink, A.J. 2003. Proanthocyanidins in health care current and new trends. Curr. Med. Chem., 10:1345-1359.

Duncan, D.B. 1955. Multiple range and F. test. Biometric, (11): 1-42.

Eid, Y.; Ebeid, T. and Younis, H. 2006. Vitamin E supplementation reduces dexamethasone-induced oxidative stress in chicken semen. British Poultry Science, 47: 350-356.

Fernandez, M.M.F. 2008. Increase and decrease of sperm production. A potent penis. Los Angeles, California, USA.

Frank, J. 2005. Beyond vitamin E supplementation: an alternative strategy to improve vitamin status. Journal of Plant Physiology, 162: 834843.

Freeman, B.M. and Vince, M.A. 1974. In: Development of the avian embryo. Champman and Hall, London, Uk, 249-260.

García-RuízA.,BartoloméB., MartínezRodríguez A.J., Puello E., MartínÁlvarez P.J. and Moreno-Arribas M.V. 2008. Potential of phenolic compounds for controlling lactic acid bacte-ria growth in wine. Food Control., 19: 835-841.

Gon i, I. and Serrano, J. 2005. The intake of dietary fiber from grape seeds modifies the antioxidant status in rat cecum. J. Sci. Food Agric. ,85:1877-1881.

Gon I, I.; Brenes, A.; Centeno, C.; Viveros, A.; Saura-Calixto, F.; Rebole', A.; Arija, I. and Esteve, R. 2007. Effect of dietary grape pomace and vitamin $\mathrm{E}$ on growth performance, nutrient digestibility and susceptibility to meat lipid oxidation in chickens. Poultry Science, 86: 508-516.

Halliwell, B. and Gutteridge, J.M. 1984. Lipid peroxidation, oxygen radicals, cell demage and disease. Biochemical Journal, 219: 1-14.

Jianguo, L. and Zhinian, I. 1990. Studies on the correlation between testosterone levels in serum and seminal plasma and semen quality. Stud Bull. J. Agric. Univ. Hebei, 2: 14-21.

Kalamah, M.A.; El-Nadi, M.M.; Goher, L.M. and Soliman, M.M. 2000. Some factors affecting fertility and hatchability using artificial insemination in Norfa chickens. 3rd All Africa Conference on Animal Agric. and 11th Conference of the Egyptian Society of Animal Production, Alex. Egypt, 6-9 November, 597-605.

Lichovnikova, M.; Kalhotka, L.; Adam, V.; Klejdus, B. and Anderle, V. 2015. The effects of red grape pomace inclusion in grower diet on amino acid digestibility, intestinal microflora, and sera and liver antioxidant activity in broilers. Turkish Journal of Veterinary and Animal Sciences, 39: 406-412.

Lin, Y.F.; Chang, S.J.; Yang, J.R.; Lee, Y.P. and Hsu, A.I. 2005. Effects of supplemental vitamin $\mathrm{E}$ during the 
mature period on the reproduction performance of Taiwan native chicken cockerels. British Poultry Science, 46: 366-373.

Llobera, A. and Can ${ }^{\sim}$ ellas, J. 2007. Dietary fiber content and antioxidant activity of Manto Negro red grape (Vitis vinifera): Pomace and stem. Food Chemistry, 101: 659-666.

Mukai, K.; Sawada, K.; Kohno, Y. and Terao. J. 1993. Kinetic study of the prooxidant effect of tocopherol. Hydrogen abstraction from lipid hydroperoxides by tocopheroxyls in solution. Lipids, 28: 747-752.

NRC. 1994. Nutrient Requirements of Poultry. 9th revised edition. National Academy Press, Washington, D.C., USA.

O“zkan, G.; Sagdic, O.; Baydar, N.G. and Kurumahmutoglu, Z. 2004. Antibacterial activities and total phenolic contents of grape pomace extracts. J. Sci. Food Agric., 84:18071811.

Papadopoulou, C.; Soulti, K. and Roussis, I.G. 2005. Potential antimicrobial activity of red and white wine phenolic extracts against strains of Staphylococcus aureus, Escherichia coli and Candida albicans. Food Technol. Biotech., 43:41-46.

Perumalla, A.V.S. and Hettiarachchy, N.S. 2011. Green tea and grape seed extracts-potential applications in food safety and quality. Food Res. Int., 44: 827-839.

Priya, K.T.; Elizabeth Manju, D.K.; Thangavel, A. and Leela, V. 2012. Dietary supplementation of alma and grapesees on testosterone concentration and semen characteristics in broiler breeders.
Tamilnadu J. Veterinary \& Animal Sciences, 8 (5): 253-258.

Puiggross, F.; Llopiz, N.; Ardevol, A.; Blade, C.; Arola, L. and Salvado, M.J. 2005. Grape seed proanthocyanidins prevent oxidative injury by modulating expression of antioxidant enzyme system. J. Agric. Food Chem., 53:6080-6086.

Puthpon-gsiriporn, S.; Scheideler, E.; Sell, J.L. and Beac, M.M. 2001. Effect of vitamin $E$ and $C$ supplementation on performance, in vitro lymphocyte proliferation, and antioxidant status of laying hens during heat stress. Poultry Science, 80:1190-1200.

Rodrigo, R.; Rivera, G.; Orellana, M.; Araya, J. and Bosco, C. 2002. Rat kidney antioxidant response to longterm exposure to flavonol rich red wine. Life Science, 71:2881-2895.

Rodrigo, R.; Castillo, R.; Carrasco, R.; Huerta, P. and Moreno, M. 2005. Diminution of tissue lipid peroxidation in rats is related to the in vitro antioxidant capacity of wine. Life Science, 76:889-900.

SASInstitute,Inc.2000.SASUser'sGuide: Statistics. SAS Inst. Inc., Cary. NC.

Scalbert, A. and Williamson, G. 2000. Dietary intake and bioavailability of polyphenols. Journal of Nutrition, 130:2073S-2085S.

Schipper,H.M.2004.Brain iron deposition and the free radicalmitochondrial theory of ageing, Ageing Res. Rev., 3: 265-301.

Sharpe, R.M. 1994. Regulation of spermatogenesis. In: The Physiology of Reproduction. (eds. E. Knobil and J. D. Neill), Raven Press, Ltd, New York, NY. 
grape pomace, vit. $E$, productive performance, semen quality.

Shi,J.;Yu,J.;Pohorly,P.E.andKakuda,Y .2003. Polyphenolics in grape seedsBiochemistry and functionality. J Med Food, 6: 291-299.

Silbergberg, M.; Besson, C.; Manach, C.; Remesy, C. and Morand. C. 2006. Influence of dietary antioxidants on polyphenol intestinal absorption and metabolism in rats. J. Agric. Food Chem., 54:3541-3546.

Sivarooban,T.; Hettiarachchy, N.S. and Johnson, M.G. 2008. Transmission electron microscopy study of Listeria monocytogenes treated with nisin in combination with either grape seed or green tea extract. J. Food Prot., 71: 2105-2109.

Sonmez,M.;Yuce,A. and Turk, G. 2007. The protective effects of melatonin and vitamin $E$ on antioxidant enzyme activates and epididymal sperm characteristics of homocysteine treated male rats. Reproductive Toxicology, 23:226-231.

Spiteller, G. 2001. Lipid peroxidation in aging and age-dependent diseases. Exp. Gerontol., 9: 1425-1457.

Surai P.F.; Fujihara, N.; Speake, P.K.; Pbrillard, J.; Wishart, G.J. and Spark, N.H.C. 2001. Polyuns.aturated Fatty Acids,Lipid Peroxidation and Antioxidant Protection in Avian Semen. Asian-Australian Journal Animal Science, 14(7):1024-1050.

Tekeli, A.; RuStu Kutlu, H. and Celik, L. 2014. Dietary inclusion of grape seed oil in functional broiler meat production. Bulgarian Journal of Agricultural Science, 20 (4): 924-932.

Torres, J.L.; Varela, B.; Garcı'a, M.T.; Carilla, J.; Matito, C.; Centelles, J.J.; Cascante, M.; Sort, X. and Bobet. R. 2002. Valorization of grape
(Vitis vinifera byproducts. Antioxidant and biological properties of polyphenolic fractions differing in procyanidin composition and flavonol content. J. Agric. Food Chem., 50:7548-7555.

Vertuani,S.;Angusti, A. and Mafredini, S. 2004. The antioxidant and proantioxidant network: An overview. Current Pharmaceutical Design, 10: 1677-1694.

Viveros, A.; Chamorro, S.; Pizarro, M.; Arija, I.; Centeno, C. and Brenes, A. 2011. Effects of dietary polyphenol-rich grape products on intestinal microflora and gut morphology in broiler chicks. Poultry Science, 90: 566-578.

Wang, M.L.; Suo, X.; Gu, J.H.; Zhang, W.W.; Fang, Q.; and Wang, $X$. 2008. Influence of grape Seed proanthocyanidin extract in broiler chickens: Effect on chicken coccidiosis and antioxidant status. Poultry Science, 87:2273-2280.

Yamakoshi, J.; Kataoka, S.; Koga, T. andAriga, T. 1999. Proanthocyanidinrich extract from grape seeds attenuates the development of aortic atherosclerosis incholesterol-fed rabbits.Atherosclerosis, 142: 139-149.

Yilmaz,Y.and Toledo, R.T. 2004. Major flavonoids in grape seeds and skins:Antioxidant capacity of catechin, epicatechin, and gallic acid. J. Agric. Food Chem., 52:255-260.

Yu, B.P. and Yang, R. 1996. Critical evaluation of the free radical theory of aging. A proposal for the oxidative stress hypothesis, Ann. N.Y. Acad. Sci.,786:111 


\title{
A.K. Alm El-Dein et al.
}

\author{
الملخص العربى فئم \\ دراسده مقارنه بين اضافة تفل العنب و فيتامين E كمضادات للاكسده على الأداء الانتاجى

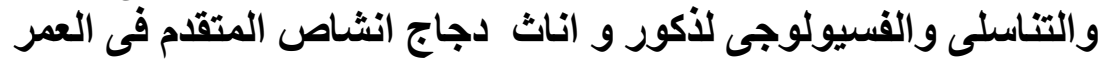

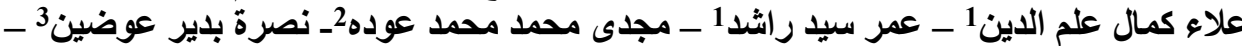

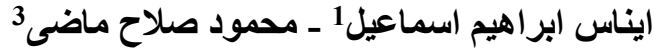
1 قسم بحوث تربية الدواجن ـ معهد بحوث الانتاج الحيو انى ـ مركز البحوث الزر اعيه ـ وزارة الزراعه

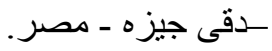
2_محطة بحوث الدو اجن (أنشاص)- معهد بحوث الانتاج الحيو انى ـ مركز البحوث الزر اعيه ـ وزارة الزر اعه . مدئ

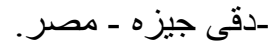
3_محطة بحوث الدو اجن (سخا) ـ معهد بحوث الانتاج الحيو انى ـ مركز البحوث الزر اعيه ـ وزارة الزر اعه

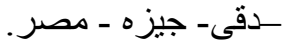

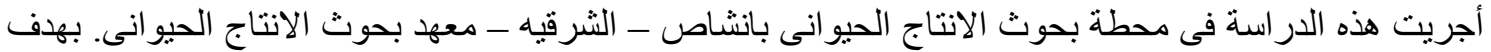

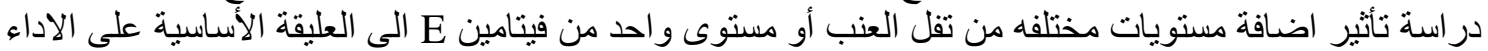

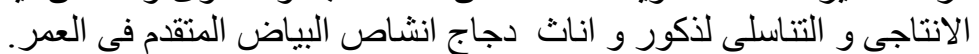

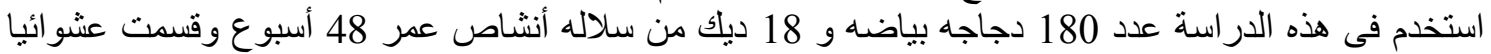

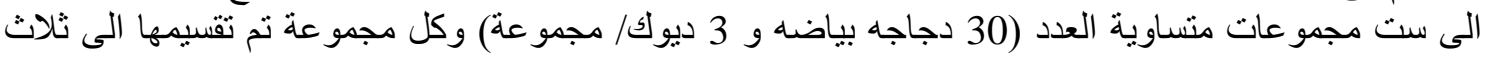

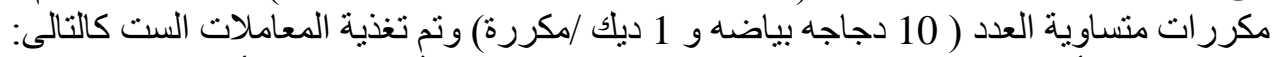

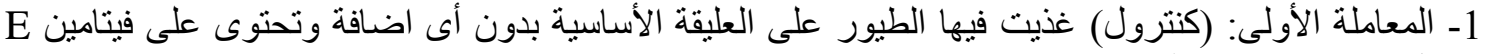
بمعدل (15 مجم/كجم عليقة).

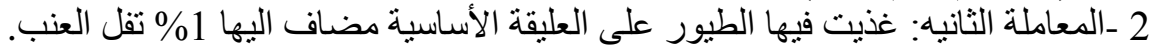

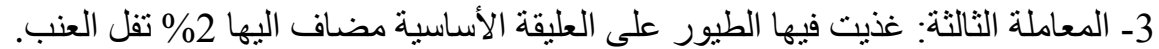

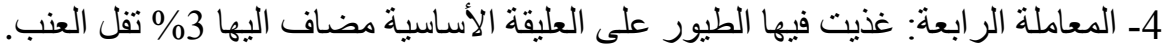

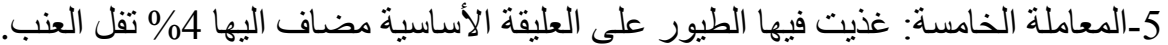

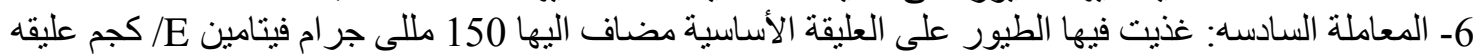

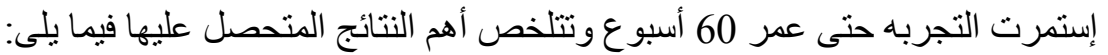

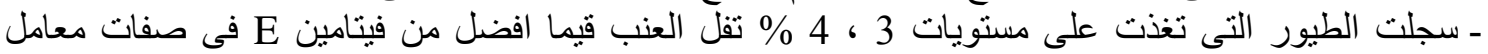

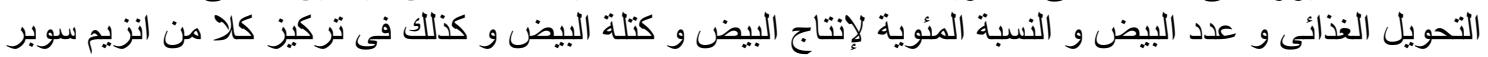

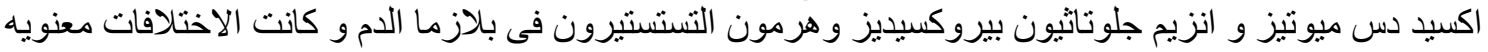

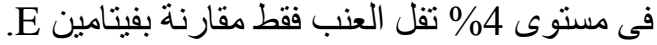

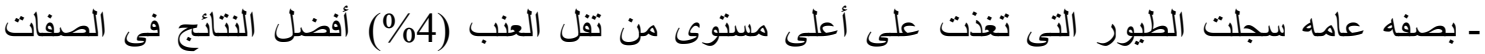

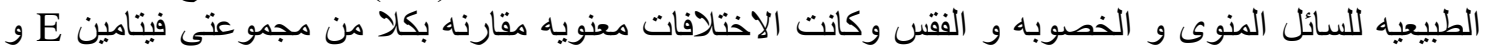

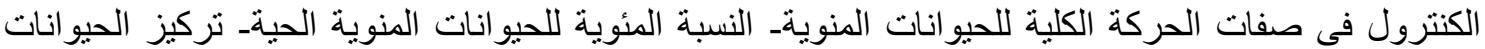

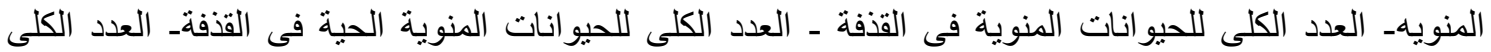

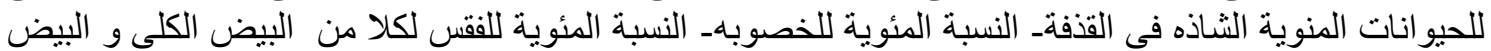

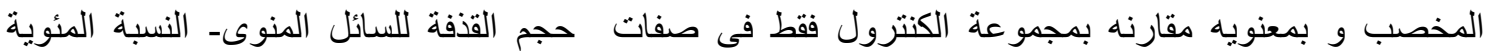

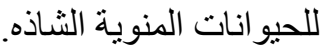

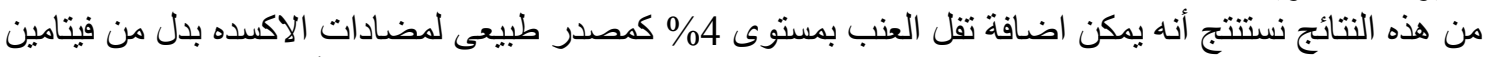

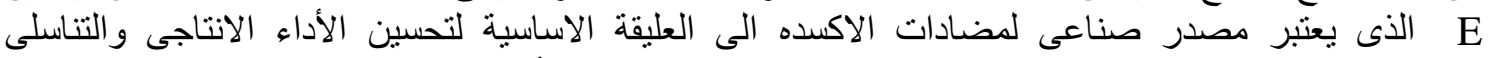

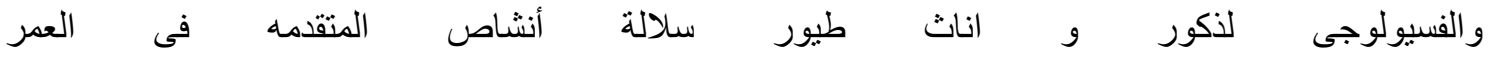


